\title{
Inledning
}

\section{Filifjonkans sällskap}

Så länge jag har sysslat med denna bok har jag haft en enveten bild på näthinnan. Det är Filifjonkan, den magra, oroliga, lätt beklagansvärda figuren i utkanten av Tove Janssons muminvärld, med sitt krampaktiga tag om skurhink och dammvippa. Filifjonkan är inte en karaktär som muminläsare brukar identifiera sig med eller känna sig dragna till. Hon har inget av Too-tickis stoiska lugn eller Muminmammans milda omnipotens. Inte heller har hon Lilla Mys befriande ilska eller Snusmumrikens åtråvärda självtillräcklighet. Snarare framstår hon som en ytterst ocharmig blandning av ångest och artighetsvisiter, en sinnebild för den olyckliga, förgrämda hemmafrun med damm på hjärnan. Filifjonkan är livrädd för inkräktare och smuts som tränger sig innanför verandadörren. Hon städar för att allt hon lärt sig i livet är vikten av att hålla skräpet stången. Städningen skapar, förstår vi, ordning i hennes inre kaos. Men den gör också omgivningen lite trevligare och mer beboelig, huset till lite mer av ett hem. Och då och då, när katastroferna väl infunnit sig och stormen bedarrat, kan den till och med upplevas som en befriande sinnlig och njutningsfull aktivitet.

Filifjonkan stannar hos mig för att hon, på ett oemotståndligt sätt, synliggör städningens dramatik och existentiella dimensioner. Städning må mestadels framstå som en trivial och ointressant sidosyssla, ett nödvändigt och trist måste. För 
Filifjonkan är den blodigt allvar. När hon rämnar och rasar och hysteriskt försöker upprätthålla styrseln med dammtrasan, påminns vi om hur sällan städning uppmärksammas - varken som praktisk erfarenhet eller som existentiell sysselsättning. Inte minst blir det tydligt hur lätt det är att avfärda både sysslan och personerna som sysslar med den som lite lätt beklagansvärda och kanske framför allt erbarmligt tråkiga.

Med Filifjonkan som ledsagare vill jag fördjupa mig i städningens dramatik. Det är städning som vardagspraktik, utförd i det privata, som jag huvudsakligen vill dröja vid - det människor gör i sina hem. Vad är städning för sorts syssla? Hur upplevs och berättas den? Och hur ska vi förstå dess existentiella dimensioner?

Mina frågor ställs från ett specifikt håll, som ju för det mesta är fallet. Som forskare inriktad på feministiska frågeställningar om makt och underordning är jag särskilt intresserad av varför en så genuskodad syssla som städning - något kvinnor i alla tider förväntats utföra - är så lågt värderad. Hur kommer det sig att omhändertagandet av vår materiella omgivning, borttagande av smuts, har så låg status i samhället? Hur ser kopplingarna ut mellan städningen, smutsen och de enskilda kroppar som utför arbetet? Vilka politiska dimensioner bär vardagsstädningen på?

Jag är även intresserad av hur städningens praktik kan kopplas till teorier om tid och temporalitet. Jag tänker mig nämligen att städningens rytm, det jag kommer att undersöka som dess särskilda temporalitet, ger en möjlig nyckel till att besvara de frågor jag vill undersöka.

\section{En oberättad vardagssyssla}

Det har inte varit helt lätt att få syn på städningens roll i kulturen. Trots att privat städning är något de flesta har stor erfa- 
renhet av, många känslor kring och praktiserar dagligdags - i det egna hemmet, i andras, åt sina barn, föräldrar eller sambos tycks den sällan vara ett ämne för uppmärksamhet. Till skillnad från andra sysslor knutna till hemmet, som exempelvis barnuppfostran, matlagning och heminredning, är det helt enkelt rätt tyst om städning som praktik.

Till skillnad från annat hemarbete finns det heller ingen medialisering av städning att tala om, såsom vi exempelvis ser i fråga om att inreda sitt hem, renovera huset, leva med barn, laga mat, sticka eller sy kläder. Även om vi, under årens lopp, har kunnat titta på ett eller annat reality-program där experter hjälper »extra smutsiga» människor att städa, kan det inte jämföras med den uppsjö av tidningar och tv-shower där inredning, matlagning och barnuppfostran står i fokus.

Det är helt enkelt något med själva städningen som gör den mindre synlig i det offentliga. I sin studie av finlandssvenska hemmafruars livsberättelser, erfarenheter som i mångt och mycket handlar om hemmet och vardagen, förklarar Lena MaranderEklund (2014) kvinnornas relativa fåordighet kring vardagssysslorna med att de förmodligen tedde sig alltför bagatellartade att nämna. Beskrivningarna av hur det gick till när vardagsrum, sängkammare och kök städades, dag ut och dag in, tycktes helt enkelt inte riktigt »berättarbara». På liknande sätt diskuterar Rita Felski (2000) tendensen hon menar sig se bland forskare att vilja studera vardagen - och samtidigt skygga för det konkreta och vardagliga. Hur lätt det tycks vara att vilja undersöka, men i praktiken så oglamoröst och på något sätt ointressant att dröja vid.

Om de vardagliga sysslorna således bär på en sorts inbyggt motstånd mot offentliggörande verkar städningen vara den kanske mest trivialiserade, bagatelliserade och oattraktiva av dem alla. 
Feminismen och städningen

Detta gäller även i feministiska sammanhang. Märkligt, kan tyckas, med tanke på städningens envetna genuskodning. Men också, kanske just därför, begripligt. Den feministiska rörelsen har nämligen ett laddat förhållande till både hemmet och hemarbetet. Felski (200o, s. 86) formulerar det till och med som ett feminismens antihem-narrativ. Att, som kvinna, lämna hemmet och skaffa sig ett betalt arbete är helt enkelt en relativt oproblematiserad feministisk uppmaning (Giles 2004). ${ }^{1}$ Från Ibsens Nora, som lämnar »dockhemmet«, över Simone de Beauvoirs beskrivning av hemarbetet som kvinnors förbannelse, till Betty Friedans deprimerade hemmafruar och Germaine Greers kvinnliga eunuck, har vägen till kvinnors självförverkligande och frihet gått bort från hemmet och ut i världen (Lloyd 1984, Johnson och Lloyd 2004, Gillis och Hollows 2009). Hemarbetet, det arbete som kvinnor ålagts och påtvingats, har därför ofta formulerats som motsatsen till just självförverkligande - som något trist, enahanda och meningslöst.

Felski pekar ut andra vågens feminism, under 1960- och 7o-talen, som särskilt investerad i rörelsen bort från hemmet. Samtidigt, vill jag påpeka, verkar detta vara en period då det obetalda hemarbetet sätts under lupp och synliggörs på alldeles särskilda sätt, åtminstone i ett svenskt sammanhang. Inte minst gäller det städningen (se t.ex. Waldén 1979). I artikeln »Disktrasa i brons. Om städning och skapande« kartlägger Barbro Werkmäster (1983) den tendens hon tycker sig se bland 1970-talets kvinnliga konstnärer att använda sig av hushållsarbete- och redskap i sina verk. Som exempel nämner hon bland annat Kvinnobulletinens första nummer från 1971, vars omslag pryds av en städande kvinna som ligger på knä under två män, liksom Dagens Nyheters serie »Kvinnokraft» från 1972, som illustreras av en rad 
porträtt av kända män, avdammade av en kvinna. Vi har också konstnären Gittan Jönssons återkommande tematiseringar av kvinnor som diskar, städar och tar hand om smutsen (varav ett av verken pryder denna boks omslag).

I mandra vågens" politisering av det personliga tycks alltså städning fylla en alldeles särskild funktion, nämligen som symbol för kvinnors orättmätiga dubbelarbete. Evighetsarbetet i hemmet framställs som den osynliga (och osynliggjorda) black om foten som gör kvinnors rörelse ut från hemmet så långsam och svår. I sin analys av konstnären Barbro Hedströms disktrasa i brons diskuterar Werkmäster (1983, s. 26) också mycket riktigt den förevigade trasan som en "första symbolisk handling $\mathrm{i}$ hopp om frigörelse från en förslavande kvinnoroll«.

Även om 1960- och 70-talen möjligen skulle kunna beskrivas som städningens prime time inom den feministiska rörelsen, verkar fokus - med några undantag - huvudsakligen ha legat på städning som politisk symbol, något att ta avstånd från och ladda med indignation och ilska. Själva praktiken, alltså den faktiska städningen, väcker mindre intresse, då som nu. På sätt och vis är det som om den politiska symbolen till viss del skymmer praktiken. Uppgiften i denna bok är därför att rikta blicken mot städning som vardagspraktik: att helt enkelt försöka dröja vid det människor sysslar med vardagligdags. På så sätt hoppas jag kunna förstå hur symbol och praktik samverkar i att göra städning till en så synnerligen laddad syssla.

Städning i forskningen

Inte heller finns det särskilt många forskningsstudier om städning som vardagspraktik. I essän "Varför skurar kvinnor toaletter?» diskuterar Yvonne Hirdman just denna avsaknad av 
teoretiskt intresse för ämnet. I texten, som publicerades 1992, uppsöker hon ett antal fiktiva företrädare för olika vetenskapliga inriktningar, för att få experternas svar. Hirdman kretsar huvudsakligen kring ett konstaterande att frågan sällan brukar tas på allvar - att forskning och teori inte brytt sig särskilt mycket om en så lågt värderad och kvinnligt kodad uppgift som städning. Inte minst, menar hon, tenderar frågan att framstå som i det närmaste pinsam. »Toaletter? Vad har toaletter med över huvud taget något att göra? Demokrati? Vetenskap?« (Hirdman, 1992, s. 123)

En illustration av Hirdmans tes kan hämtas från en av de få avhandlingar i Sverige som direkt uppehållit sig vid städning i hemmet, nämligen arkitekten Gudrun Linns från 1985. I Badrum och städning. Hur ska badrum byggas för att underlätta städningen? undersöker Linn Svensk Byggnorms detaljerade minimimått för utrymmen i badrum ur städsynpunkt - det vill säga hur standarden korresponderar med erfarenheter av att få utrymmet rent. Detta var något ingen tidigare gjort och reaktionerna lät inte vänta på sig. Dagen innan disputationen publicerade Dagens Nyheter en debattartikel av en docent på Kungliga Tekniska Högskolan som menade att forskningen var löjeväckande (Johansson 1985). Att i tio års tid undersöka bästa sättet att göra rent sitt badrum med borste och trasa var, enligt forskaren, bortkastad forskarmöda. Även andra medier hängde på och Gudrun Linn fann sig löpa gatlopp, offentligt förlöjligad som »dassdoktorn» (Linn 2005).

Trots att Linns avhandling publicerades 1985 och en del vatten har runnit under broarna sedan dess (bl.a. kom hennes studie i slutändan att resultera i ändrad byggstandard vad gällde toaletter), genererar städning i hemmet fortfarande påfallande litet forskarintresse. Framför allt lyser de kulturanalytiska stu- 
dierna med sin frånvaro (se Pink 2004, Martens 2007). ${ }^{2}$ Däremot finns det närliggande forskningsfält som tangerar frågor om renhet, smuts och rengöring. Bland annat gäller det forskning om det obetalda arbetet i hemmet, där jämställdhet och arbetsdelningen mellan könen ofta står i centrum (se t.ex. Elwin Novak 1999, Hageman och Roll-Hansen 2005, Magnusson 2006, Platzer 2009, Aarseth 2011). I dessa studier diskuteras städning som en integrerad del av allt det omsorgs- och hushållsarbete som någon i hemmet måste sköta.

Att denna någon huvudsakligen är av kvinnokön är utgångspunkten för de studier som fokuserar hemmafruns villkor och tillvaro. Vissa av dessa bygger på historiskt arkivmaterial och analyserar huvudsakligen tiden före 1970-talet (se t.ex. Palmer 1989, Shove 2003, Johnson och Lloyd 2004), andra använder sig av etnografiska metoder och analyserar kvinnors nutida berättelser om sin hemmafrutillvaro tidigare i livet (Åström 1986, Danielsen 2002, Marander-Eklund 2014). Här skrivs en sorts alternativ historia om alla de sysslor som huvudsakligen varit kvinnors ansvar, men sällan kvalificerat sig som riktigt arbete. En pionjär på området är Ann Oakley, som i The Sociology of Housework (1974) intervjuade hemmafruar i 1970-talets Storbritannien. Oakleys utgångspunkt är att betrakta hemmasysslorna som ett arbete i sin egen rätt. Hennes slutsats är att detta arbete karakteriseras av att vara obetalt, ensamt, mestadels tråkigt och mycket monotont. Om självständighet var den kvalitet som kvinnorna i Oakleys studie uppskattade mest med sitt hemarbete så var, symtomatiskt nog, hushållssysslorna de lägst värderade. Allra minst uppskattades disk, strykning - och städning (Oakley 1974, s. 42).

Om det obetalda hemarbetet ges en specifik mening när det utförs av en hemmafru, blir det delvis annorlunda kodat när 
det lejs ut till andra. Forskning om hushållsarbete i andras hem - liksom om (den växande globala) marknaden för hushållstjänster i hemmen - är relativt omfattande. I ett svenskt sammanhang har införandet av skatteavdrag på hushållsnära tjänster (där bland annat städning ingår) stått i fokus för studier om såväl arbetsgivare som arbetstagare (se t. ex. Björklund Larsen 2010, Calleman och Gavanas 2013, Kvist 2013, Petersson 2013). Ett viktigt perspektiv i denna forskning är hemarbetets gradvisa globalisering (Anderson 200o, Ehrenreich och Hochschild 2004). Under 2000-talet har tillgången på billiga hushållstjänster ökat, delvis som ett utslag av ökade inkomstskillnader, delvis som en effekt av en global postindustriell serviceekonomi med ökad tillgång på arbetskraft (Calleman och Gavanas 2013). Idag är det alltfler fattiga (företrädesvis) kvinnor i syd och "öst" som reser för att städa hemmen i nord, ibland med andra typer av inresetillstånd, sämre villkor och lägre löner än andra migranter, vilket signalerar att hemarbete inte är att betrakta som riktigt arbete (Sassen 2006, Cox 2011, Lutz 2011). ${ }^{3}$

Som synes finns det en rad forskningsfält som gränsar till de frågor jag fokuserar i denna bok och som jag kommer att använda mig av framöver i mina analyser. Däremot är det påfallande sällan själva städningen spelar huvudrollen. Bland de få studier som undersökt städning som vardagspraktik återfinns emellertid Sarah Pink (2004), som i sin etnografiska monografi Home Truths (2004) jämför städvanor i Spanien och England. Pink betraktar städning som en kreativ och sinnlig syssla, genom vilken människor skapar mening i vardagen. Hon konstaterar att de flesta hon intervjuade hade starka åsikter om exakt hur städning bör gå till, samtidigt som de tog avstånd från normer de upplevde som tvingande. Som en tydlig motbild målas hemmafrun upp, hon som är besatt av hemarbete och inte har annat 
för sig. Till skillnad från hemmafrun beskriver framför allt de intervjuade kvinnorna att de städar när andan faller på. Männen däremot formulerade snarare hemarbetet som ett äventyr de ger sig in i. Medan det för kvinnorna framstod som långt viktigare att ha kontroll över hemarbetet så att det inte tog överhanden, betraktade alltså männen arbetet som något att klara av och bemästra.

Även Lydia Martens (2007) studie av städpraktiker i England visar hur städningen har blivit alltmer individualiserad, hur städpraktiker mindre genomsyras av tradition och moral än av föreställningar om individens eget val. Martens föreslår att vi har att göra med en ny kulturell standard som snarare baseras på estetik än på en cyklisk ordning. Hennes intervjupersoner balanserade mellan två möjliga modeller av smutshantering: den ena handlar om en vilja att ha kontroll över situationen och hemmet, den andra om att undvika att framstå som alltför kontrollbenägen (och därigenom som en hysterisk hemmafru).

Sammanfattningsvis kan jag konstatera att även om forskare har intresserat sig för frågor om smuts och renhet, hemarbetets genuskodning, globalisering och kommersialisering är det få studier som dröjt vid upplevelser och erfarenheter av att städa i det egna hemmet. Jag vill därför, i denna bok, göra just detta.

Smutsen och samhällsordningen

Det finns många sätt att teoretiskt närma sig frågan om städning i hemmet. Här vill jag kort redogöra för några av de tankegångar som är viktiga för mina kommande analyser.

En teoretiker som haft stort inflytande på diskussioner om renhet och smuts är Mary Douglas. I sin numera klassiska korskulturella studie Renhet och fara pläderar Douglas (1966) för att 
smuts inte är en absolut, isolerad företeelse. Snarare måste den betraktas som »matter out of place», det vill säga materia som hamnat på fel plats. Leriga stövlar är exempelvis smuts när de placeras på köksbordet, men inte ute på gårdsplanen. Smuts, enligt Douglas, förutsätter två villkor: dels en uppsättning ordnade förhållanden, dels en kränkning av den ordningen. Människors föreställningar om smuts och renhet är därför först och främst att betrakta som upprätthållande av sociala och symboliska ordningar.

Douglas teori ligger i linje med hur Norbert Elias (1939/1989) har beskrivit smutsens roll i utvecklingen mot ökad civilisation i framför allt västvärlden. Elias argumenterar för att ökad renlighet och självbehärskning kännetecknar framväxten av den moderna individen. Framför allt, hävdar han, var den successivt förändrade inställningen till smuts avgörande för hur social kontroll försköts från en yttre till en inre styrning, där medborgarna själva lärde sig att kontrollera sina begär, behov och kroppsliga utsöndringar. I kritisk dialog med såväl Douglas som Elias har forskare tagit smutsen som utgångspunkt för att undersöka hur människor organiserar sin vardag (se t. ex. Hoy 1997, McHugh 1997, Campkin och Cox 2007, Lagerspetz 2007).

Om det är möjligt att tala om ett smutsens teoretiska fält kan Julia Kristevas utveckling av Douglas tankegångar få illustrera dess inriktning mot en mer abstrakt analys. "Smuts», menar Kristeva (1992, s. 94), »representerar den symboliska ordningens objektiva bräcklighet» och "orenhet är det som faller ur det symboliska systemet». Dessa tankegångar har varit betydelsefulla, inte minst för att de relativiserar föreställningar om hygien och lyfter dess symboliska och samhällsorganiserande betydelser. Omhändertagandet av smutsen aktualiserar här existentiella frågor om liv, död, omsorg och förgänglighet. 
Kvinnan, hemmet och reproduktionen

Mary Douglas relativisering av smuts som en fråga om ordning och oordning ställer platsen i centrum. Smuts är helt enkelt det som hamnat på fel plats i tillvaron - och platsen kan således betraktas som central för synen på städning. Inte minst gäller detta gränserna mellan offentligt och privat, hemmet och världen utanför. Förståelsen av plats, och inte minst hemmet som plats, är därför viktig för en analys av städning som praktik.

Förståelsen av hem är i sin tur oundvikligen sammanlänkad med genus (Lloyd 1984, Massey 1994, Felski 2000, Young 2000). Trinh T Minh-ha (1994, s.15) talar exempelvis om den naturaliserade bilden av kvinnor som »keepers of home« och Luce Irigaray (1992) konstaterar att kvinnans roll är att vara hemmet genom att vara hemma. Denna kulturella koppling mellan kvinnor, hem och det privata har, av feministiska forskare, bland annat analyserats i relation till uppdelningen mellan natur och kultur (se t.ex. Solheim 1998). I sin numera klassiska artikel »Is Female to Male as Nature to Culture» diskuterar Sherry Ortner (1974) hur kvinnor världen över betraktas som närmre naturen än män, som »less transcendental of nature than men« (s. 73). En anledning till detta är, enligt Ortner, kvinnors fysiologi: genom sin förmåga att menstruera, föda barn och ge barnet bröstmjölk uppfattas kvinnokroppen som närmre naturen än mäns kroppar. Dessutom menar Ortner att den sociala miljö kvinnan förpassas till (dvs. hemmet) och de sysslor hon åläggs kopplas mer till natur än kultur. Hemmet har nämligen betraktats som en trygg och stabil plats bortom den kulturellt föränderliga omvärlden, och hemarbetet just som en sorts återskapande av en naturlig och till synes förkulturell ordning, där maten måste lagas, sängarna bäddas och barnens näsor snytas alldeles oavsett vad som händer i världen utanför. 
Samtidigt är hemmet platsen där kulturaliseringen tänks ske, där råvaror omvandlas till ätbart och där barn socialiseras till medborgare. Denna omvandling från natur till kultur är kvinnans uppgift. Hennes roll skulle således, enligt Ortner, kunna beskrivas som en sorts medlare mellan just natur och kultur och det arbete hon utför - hemarbetet - kretsar kring att hantera och parera denna paradox (jfr McHugh 1997). ${ }^{4}$

Den synnerligen ambivalenta position som kvinnan har ålagts: att som potentiellt oren (dvs. närmre naturen) själv garantera moralisk fysisk ordning (dvs. kultur) i hemmet, har i sin tur analyserats i relation till föreställningar om sexualitet (Lloyd 1984, Palmer 1989, McHugh 1997). Genom att hålla ordning i hemmet vaktar, upprätthåller och organiserar kvinnan de symboliska gränserna mellan inne och ute, offentligt och privat, natur och kultur. Hemmet blir då att betrakta som en symbol för kvinnans kropp och, i förlängningen, hennes respektabilitet. Ett städat hem signalerar följaktligen en respektabel, ärbar och ren kvinna (Solheim 1998). Kvinnlighet har således historiskt definierats delvis av hur kvinnan hanterar smuts. Och omvänt formulerat: kvinnors städning kan betraktas som en syssla som bildar ramverk för synen på deras sexualitet (McHugh 1997, Palmer 1998).

De teorier jag återgivit intresserar sig huvudsakligen för hur kvinnan som kulturell symbol och kvinnor som kollektiv relateras till hem, hemarbete och natur. Det är emellertid omöjligt att blunda för att vissa kvinnor associeras mer kraftfullt till natur, hem och vardag än andra - något som många forskare påpekat(se t. ex. Skeggs 1997, Felski 200o). På liknande sätt som kvinnor kulturellt har associerats med natur har även arbetarklass, icke-vita och sexuellt avvikande betraktats som okultiverade, smutsiga och potentiellt farligt okontrollerade (McHugh 1997, 
Cox 2007). Att reglera närheten till smuts, det vill säga vem som städar och vem som inte gör det, vem som riskerar att smutsas ner och vem som kommer undan, blir således en fråga som inte enbart handlar om genus utan även om andra maktrelationer, något som kommer att visa sig i mina analyser framöver (jfr Hill Collins 1998).

\section{Det obetalda arbetet}

Eftersom kvinnor generellt har kommit att både associeras med och symbolisera hemmet, blir de sysslor som utförs hemmavid av särskilt teoretiskt intresse. Med avstamp i den marxistiska uppdelningen i produktivt och reproduktivt arbete (dvs. avlönat arbete utanför hemmet som producerar mervärde kontra oavlönat arbete i hemmet som syftar till att återskapa och upprätthålla liv) har feministiska forskare undersökt och diskuterat hemarbetets status som just arbete (Anderson 2000, Roman 2004). ${ }^{5}$ Vilken sorts verksamhet är egentligen arbetet $\mathrm{i}$ hemmet? Och vilken roll spelar vår förståelse för de villkor, rättigheter och den status sysslan har? Ann Oakley (1974) pläderade, som sagt, för att hemmasysslor som disk, tvätt, städning, barnomsorg och matlagning snarare än ett uttryck för kärlek, familjelojalitet och omsorg måste betraktas som just ett arbete, ett synnerligen krävande sådant. En av Oakleys poänger var att synliggöra hemarbetet som en väsentlig del av samhällsekonomin, det vill säga att behandla det reproduktiva arbetet som produktivt snarare än improduktivt. Hemarbetet utgör helt enkelt förutsättningen för att produktionen alls ska fungera (se även Hageman och Roll-Hansen 2003, S. 11). Så sett profiterar kapitalet på det mervärde som produceras i hemmet (Dahlström 1962, Dalla Costa och James 1973). 
Andra forskare har emellertid påpekat att ett sådant perspektiv på hemarbete inte förklarar varför det just är kvinnor som hamnar med disken, dammsugningen och matlagningen (Rich 1980). Heidi Hartmann (1981) menar exempelvis i en tongivande artikel att själva genusrelationerna tenderar att förbli oanalyserade. Hon poängterar att kvinnors obetalda arbete i hemmet inte enbart gynnar kapitalet. Även männen profiterar på en sådan arbetsdelning, genom att kvinnor dels utför en rad obetalda sysslor som de själva slipper och dels (pga sitt dubbelarbete) inte konkurrerar med männen på arbetsmarknaden. Sålunda måste vi, enligt Hartmann och många andra feministiska forskare, inkludera patriarkatet och den heterosexuella samlivsformen i analysen av hemarbetet (se även Delphy 1984, Jonasdottír 1991).

I Familjen i det moderna beskriver Christine Roman (2004) hur den marxistisk-feministiska analysen av hemarbete som arbete successivt har modifierats. Hon menar att hemmet och familjen idag allt oftare diskuteras som en plats för omsorg och solidaritet, snarare än enbart arbete - vilket hon lokaliserar till en ökad uppmärksamhet på skillnaden mellan »hushållsarbete» och »omsorgsarbete» (se t. ex. Waerness 1983, Gardiner 1997). Omsorgen av barn, lyder argumentationen, går inte lika lätt som exempelvis städning och matlagning att beskriva som produktion av varor och tjänster. Det arbete som sker i hemmet går således inte helt att jämställa med betalt arbete i offentligheten. Denna förskjutning i fokus erbjuder en annan syn på såväl hemarbete som på människors (företrädesvis kvinnors) olika investeringar i de obetalda sysslorna - något jag kommer att diskutera mer ingående i senare kapitel. 


\section{En annan tid}

De teoretiska ramverk jag hittills presenterat-och som framöver kommer hjälpa mig att förstå städning som syssla - behandlar dikotomier som smuts/renhet, manligt/kvinnligt, offentligt/privat, natur/kultur och arbete/omsorg. De skulle kunna sammanfattas som teorier om genus/sexualitet, makt, plats och arbete. Jag ska nu fördjupa mig i ytterligare en teoretisk ingång som jag tänker mig är central för att förstå städningens karaktär, nämligen tid. Städning är ju en syssla som på en mängd olika sätt har att göra med tid och tidsuppfattning. Att städa är repetitivt, något som många anger som anledning till varför de skyr arbetet. Det uppfattas som improduktivt: snarare än att skapa något nytt återställer det enbart det befintliga och karakteriseras därför som cykliskt. Städningen sker dessutom i hemmet, en plats som brukar associeras med den statiska, stillastående tiden. Städningen och upplevelserna av den är alltså intimt sammankopplad med tid och tidsuppfattning. Jag ska därför beskriva några teoretiska förståelser av tid som haft betydelse för min analys.

Övergången från bondesamhälle till kapitalistiskt industrisamhälle (någon gång under 18oo-talet och framåt) har delvis diskuterats som en fråga om förändrad tidsuppfattning i relation till arbete. Från att tillvaron hade bestått av en rad skilda sysslor som behövde göras på gården, i hemmet och utanför, kom arbetet $\mathrm{i}$ industrin att ruta in dagen i tydliga sjok: arbetstid och fritid. På så sätt konstruerades en tidsmässig uppdelning mellan det så kallade produktiva lönearbetet (som skedde utanför hemmet) och så kallat reproduktivt arbete (utfört utan betalning i hemmet) - en arbetsdelning som till stora delar var genuskodad. Yvonne Hirdman (2007) talar retoriskt om en "hantid" och en "hontid» för att beskriva hur denna uppdelning inverkade på kvinnor respektive män. Männens reglera- 
de, uppstyckade och avgränsade arbetstid kom, menar hon, att strukturera samhället in i minsta detalj. Kvinnors arbetstid, som snarare än att vara avgränsad inföll jämt och lite när som helst, blev därigenom både svårare att få syn på och mindre erkänd som just arbetstid.

Uppdelningen $i$ hon- respektive hantid har av andra feministiska forskare formulerats som en fråga om cyklisk respektive linjär tid, två motsatta tidsvärldar knutna till kvinnor respektive män (t.ex. Forman 1989). Med utgångspunkt i förmågan att reproducera liv menar exempelvis Julia Kristeva (1982) att kvinnors tid inte är civilisationens linjära framåtskridande, utan snarare en cyklisk, repetitiv, arkaisk tid och därigenom mer ursprunglig.

I Doing Time kritiserar Rita Felski(200o) denna smått abstrakta uppdelning mellan en cyklisk vardagsbaserad hontid och en hantid grundad i modernismens idé om ständig utveckling. Jämför vi vardagsliv skiljer sig mäns och kvinnors erfarenheter av repetition och monotoni inte särskilt mycket åt, menar hon. Att var dag pendla till jobbet och arbeta åtta timmar för att sedan ta tåget tillbaka hem är inte mindre repetitivt än att laga frukost, bädda sängar, lämna barn i skolan och hämta dem igen. Inte heller, menar Felski, är kvinnor mindre beroende av att tänka i termer av livslinjer och utveckling än män, vilket vore fallet om de levde enligt en »annan« tid. »Kvinnors tid» är alltså också strukturerad av föreställningar om succession inte minst gäller det den feministiska rörelsens berättelse om en ständig historisk utveckling framåt.

En liknande kritik formulerar Miriam Glucksman (1998) i sin studie av kvinnliga arbetare i mellankrigstidens England. Genom att jämföra två grupper av kvinnor, vävare och diversearbetare, argumenterar Glucksman för att kvinnornas olika 
tidsuppfattningar måste förstås som en fråga om skilda arbetsuppgifter och arbetsvillkor, snarare än genus. »There was nothing 'natural' about the circumstances of either group, and it would be quite misleading to view one, by implication, as more 'womanly' than the other.» (s. 254)

Även om inte all feministisk forskning skriver under på idén om en kvinnlig respektive manlig tid, har feministiska forskare ofta ifrågasatt konventionella former av tidsindelning (se Felski 200o, Fjelkestam 2012). En sådan teoretisk ansats är den som går under namnet "queer temporalitet«. ${ }^{6}$ Här diskuteras hur den samtida normativa tidsuppfattningen, den så kallade krononormativiteten, är djupt förbunden med det kapitalistiska samhällets ideal om framsteg, tillväxt och konsumtion (Freeman 2010). Även reproduktionen inbegrips i denna tidsuppfattning, genom föreställningar om en naturlig biologisk klocka som präglas av succession och framtidsorientering. Livet består av en rad hållplatser vi förväntas passera i en viss ordning på väg mot ålderdomen, där reproduktion i form av par-, familjebildning och inte minst barnalstring intar en central plats. Via familjebanden förväntas både ekonomiskt välstånd och moraliska värderingar överföras från en generation till nästa och på så sätt binda samman familjen med nationens förflutna och dess tänkta framtid.

Till skillnad från tidigare feministiska teoretiker som placerar reproduktionen i den cykliska/alternativa tidsordningen, argumenterar alltså forskare som Judith/Jack Halberstam (2005) och Elizabeth Freeman (2010) för att det sanktionerade, normativa livet - det liv som levs inom ramarna för krononormativiteten - är ett liv som producerar barn. Den duktiga produktiva samhällsmedborgaren är helt enkelt även en effektiv reproduktionsapparat (jfr Lee 2012, s. 9). Lee Edelman (2004) går så långt 
som att peka ut just barnet som den ultimata symbolen för idén om det ständiga framåtskridandet. Investeringen i framtiden, gestaltad genom bilden av barnet, beskrivs av Edelman som krononormativitetens kärna. Queer temporalitet - och de liv som levs på tvärs med krononormativiteten - framstår därigenom som en sorts ofruktsamhetens och misslyckandets tid.

Om queer temporalitet är ett möjligt begrepp för att fånga hur tid organiseras (hetero)normativt, är power-chronography ett annat. I boken In the Meantime. Temporality and Cultural Politics pläderar Sarah Sharma (2014) för att temporalitet måste förstås som "power relations as they play out in time» (s. 4). I ett samhälle där tid alltmer betraktas som en bristvara, kommer också maktrelationer att organiseras kring tid. Sharma menar att ett politiskt fokus på gemensamma platser, såsom tillgång till offentligheten, fri natur eller rekreationsområden, samtidigt bygger på tillgång till tid. Möjligheten att ta sig tid att läsa en debattartikel, ta tåget ut till havet eller demonstrera på torget bygger på tillgång till tid likaväl som till plats, något hon påpekar kraftigt begränsar det offentliga samtal som demokratin bygger på.

Tid upplevs och värderas också olika i samhället. Den stressade affärsmannens tid behandlas ofta som mer värdefull än den tid taxichauffören använder för att köra honom till flygplatsen - tid som kan vara nog så stressig. Att vissa vill ha det välstädat hemma inför helgen, innebär att andra måste arbeta kväll eller andra obekväma tider på dygnet. Sharmas poäng är helt enkelt att visa hur skilda upplevelser av och tillgång till tid är en fråga om makt. Hon pläderar för en sorts temporalisering av plats, det vill säga ett medvetandegörande om tidens betydelse för vår tillgång till världen.

Dessa teoretiska perspektiv på tid och tidsuppfattning har, 
som synes, lite olika fokus. Gemensamt för dem är emellertid att de förstår tid som normativt organiserad - som en fråga om makt och tillgång till plats, utrymme och tolkningsföreträde. Därutöver beskrivs den förhärskande tidsuppfattningen som linjär och framtidsinriktad, vilket resulterar i att såväl dåtid som »repetitiv tillvaro« framstår som förlegad, problematisk, samhällsonyttig och ointressant. På så sätt skapas också en schematisk uppdelning mellan en tänkt cyklisk och en linjär tid och tidsuppfattning - en uppdelning som är synnerligen genuskodad.

I ett försök att undkomma denna uppdelning föreslår Fanny Söderbäck (2012) begreppet revolutionär tid. Snarare än att förstå tid som antingen cyklisk eller linjär talar Söderbäck om "upprepning-med-en-skillnad". Med det menar hon en sorts återvändandets rörelse som varken idealiserar dåtiden eller bortser från den (jfr Lee 2014). Denna insikt, att tiden så att säga både löper linjärt och cykliskt, får vi genom kroppen. Genom att erkänna det som den linjära tiden trängt undan, nämligen kroppen, kommer vi bättre åt det levande lager av tid som andra tidsuppfattningar saknar. Med utgångspunkt i kroppen och dess erfarenheter, såsom det repetitiva vardagsarbetet, öppnas alltså nya sätt att förstå det förflutna, nuet och framtiden.

Även om tid och temporalitet naturligtvis inte är det enda sättet att analysera en syssla som städning, kommer jag framöver att ha tid särskilt i åtanke i mina analyser. Jag tänker mig nämligen att ett temporalt angreppssätt på städning kan hjälpa mig att besvara min ursprungliga fråga om städningens dramatik och hur det kommer sig att omhändertagande av smuts har så synnerligen låg status i samhället. 


\section{Upplägg, metod och form}

Hur har jag då gått tillväga för att få svar på mina frågor? Vilken sorts material är boken baserad på? Eftersom jag är intresserad av att resonera kring människors upplevelser av att städa sina hem: hur de gör, men också vad de känner, tänker och upplever under själva städandet, har jag huvudsakligen gjort intervjuer. Dessa har genomförts med ett drygt trettiotal personer som skiljer sig åt på en mängd vis. Jag har intervjuat kvinnor såväl som män, heterosexuella och hbtq-personer, människor från trettio- upp till åttioårsåldern, bosatta i större städer, på mindre orter och landsbygden. De har yrken som exempelvis journalist, bonde, tjänsteman, forskare, städerska, förskollärare och konstnär och är födda både i Sverige och utomlands. De lever också på olika sätt: vissa är samboende, andra lever själva, vissa med barn och någon i kollektiv.

Intervjuerna, som tagit mellan fyrtio minuter och två och en halv timme, har även formmässigt sett lite olika ut.? I sex fall har jag valt att intervjua båda parterna i en samboende parkonstellation (både homosexuella och heterosexuella par). Dessa intervjuer har bidragit med intressant information om positioneringar relaterade till hushållsarbete i hemmet. I ett av fallen skedde samtalet i form av en parintervju, vilket gav en unik inblick i det pågående förhandlandet kring städning som syssla (jfr Martinsson 1997, Norberg 2009).

De flesta av intervjuerna genomfördes i personens eget hem (ett fåtal i caféliknande miljö och en på personens arbetsplats). Oftast började samtalet vid köksbordet, för att sedan fortsätta till andra utrymmen i hemmet. I vissa fall blev de nästan att likna vid det som kallas "promenadintervjuer«, där intervjupersonen under samtalets gång visar forskaren runt i de miljöer som diskuteras (se Kusenbach 2003, Bäckman 2009, Göransson 
2012). Även om promenaderna i dessa fall var relativt korta (vi rörde oss som mest mellan vardagsrum och kök, toalett och sovrum), upplevde jag tillgången till den plats vi pratade om, det vill säga hemmet där städningen utfördes, som en stor fördel. Dels underlättade det för mig att göra mig mer konkret. Frågor som: „Var börjar du städandet? Tycker du att det är stökigt nu? Kan du visa mig hur du gör?« syntes mer relevanta ställda i själva hemmiljön. Svaren jag fick blev också, genom anknytningen till platsen, mer konkreta. »Jo, jag börjar alltid i det där hörnet.» Eller: „Du får verkligen inte gå ner i källaren och titta på familjekaoset, där går gränsen!»

Jag upplevde också att närvaron på platsen fick mina kanske till synes banala frågor att framstå som något mer meningsfulla. Att peka, visa, låta mig känna på kletet ovanpå fläkten eller undvika att öppna dörren till vissa ostädade rum, tydliggjorde (förmodligen både för mig och intervjupersonerna) de existentiella dimensioner som städningen och smutsen i det egna hemmet aktualiserar. Inte minst synliggjordes den intimitet som utelämnandet av den privata smutsen tenderar att skapa (se även Pink 2012).

Den relativa spridningen av informanter för lätt tankarna till idéer om representativitet och generaliserbarhet. Så är emellertid inte fallet. Jag har inte varit ute efter att kartlägga sanningen om vardagsstädning. Inte heller vill jag betrakta de intervjuade personerna enbart som representanter för olika positioner eller identiteter. Istället ser jag intervjumaterialet som enskilda människors försök att skapa meningsfulla berättelser i just den specifika situation som intervjuandet innebär (jfr Ehn och Löfgren 2012, 29f.). Intervjuerna blir därför att betrakta som en form av social interaktion, där inte minst forskaren (dvs. jag själv) är en aktiv deltagare (jfr Jonsson 2015). De samtal som ut- 
spelat sig ska således ses som ett resultat av mötet mellan mig och de intervjuade personerna - och mina analyser av materialet som möjliga tolkningar av de berättelser som dessa möten genererade (jfr Aull Davis 2008).

Denna syn på vetenskap betyder i sin tur att forskarpositionen inte kan betraktas som en neutral plats från vilken kunskap produceras. Snarare blir det viktigt att, som forskare, göra sig medveten om sina utgångspunkter och »utkikspunkter«: alltså såväl underliggande intresseområden och antaganden som den egna positionens betydelse för kunskapsproduktionen (Haraway 1988). Så, hur skulle jag då vilja ringa in jaget som skriver denna bok om vardagsstädningens praktik och politik? En person som i tonåren slukade Maja Ekelöfs Rapport från en skurhink, för allt den berättade om orättvisor baserade på klass och kön och för hur den, med en röst från sidan och underifrån, intervenerade i en vänsterrörelse som lätt bortsåg från kvinnors liv och arbete. En genusforskare med siktet inställt på att dröja vid, undersöka och uppmärksamma det obetalda kvinnoarbetet. En antropolog med särskilt intresse för hur människors vardagspraktiker, sådant vi sällan lägger stor vikt vid, strukturerar tillvaron och livet. En person vars mamma är uppväxt med hembiträden från Tyskland och Norge och vars pappa hade en mamma som arbetat som piga. En person som i vardagen självmant valt städningen framför tvätten i hemmet, som är smått missnöjd med att inte ha lyckats involvera sina barn tillräckligt i den dagliga renhållningen, men ändå för det mesta tycker det är rätt vilsamt att damma, ordna och dammsuga, så länge hon får vara ensam och lyssna på radio.

Även om ett dylikt sätt att försöka karakterisera forskarens position och utgångspunkter med nödvändighet är både ofullständigt och vagt, kan det ses som en påminnelse om hur 
kunskap alltid är situerad, alltså hur forskaren, genom sin särskilda utblick på världen, formar såväl fältet som den slutgiltiga produkten. En annan aspekt av hur fältet och forskaren gemensamt formar materialet är valet av intervjupersoner. Jag har huvudsakligen arbetat med det som kallas »snöbollsmetoden", som innebär att informanter tipsar vidare om andra personer som kan tänkas delta i studien (se Widerberg 2002). Snöbollsmetoden brukar användas för att få tillgång till intervjupersoner i fält som upplevs som svåra att fă tillträde till på officiell väg. En annan anledning kan vara att, genom intervjupersonernas tips, söka ringa in ett svårdefinierbart fält (Lindberg 2012).

Ingen av dessa anledningar stämmer emellertid på min studie. Människors erfarenhet av städning i hemmet kan varken betraktas som ett avgränsat fält eller som särskilt svårt att få folk att vilja prata om. Snarare tvärtom. Jag har överösts av tips (från såväl intervjupersoner som vänner, bekanta och kollegor) på personer jag borde intervjua om just städning. Urvalsprocessen har således snarare rört sig om att sålla bland förslag på möjliga informanter. Denna sållning har skett med två riktlinjer för ögonen: Dels har jag velat hitta personer som har en aktiv relation till städning, det vill säga sådana för vilka ämnet tycks relevant och viktigt. Dels har jag velat samla berättelser med olika perspektiv och utgångspunkter. I slutändan kom detta att generera en relativt brokig samling intervjuer med personer med olika livsvillkor och erfarenheter. Samtidigt är det omöjligt att bortse från materialets övervikt av kvinnor. De tips på personer jag fick var helt enkelt huvudsakligen kvinnor, något jag i förstone försökte parera genom att själv leta reda på män att intervjua. I slutändan valde jag emellertid att se genusasymmetrin som ett tecken på den starka kulturella kopplingen mellan städning 
och kvinnligt genus, vilket är en fråga som min kommande analys också kretsar kring.

Trots att städning som ämne inte direkt brukar sorteras under de mer etiskt känsliga har många av intervjuerna snabbt störtdykt ner i existentiella frågor om livets mening och tillvarons förgänglighet. Vikten av att fundera över forskningsetik har därför varit minst lika betydande som i mina tidigare studier av så kallade känsliga ämnen (t.ex. sexualitet och htbq-frågor) (se Ambjörnsson 2004, 2011). De intervjuade personerna har anonymiserats genom pseudonymer. I vissa fall har även platser, arbetsplatser och hänvisningar till familjeförhållanden ändrats, för att i mesta möjliga mån säkra anonymiteten. De längre intervjucitat som jag upplevt som potentiellt känsliga har jag låtit berörda intervjupersoner läsa och kommentera, synpunkter jag hörsammat så gott jag kunnat (jfr Nylund Skog 2012).

Utöver intervjuerna har jag, i samarbete med Dialekt- och Folkminnesarkivet i Uppsala, samlat in berättelser om städning i enkätformat. På uppmaning av arkivet har frivilliga personer, sådana som på olika sätt kommit i kontakt med informationen om min studie på nätet, skriftligt svarat på mina frågor om städning. ${ }^{8}$ De 20 personer som generöst tog sig tid och skrev ner sina erfarenheter var mellan 21 och 75 år och boende i hela landet. Även här visade sig genus vara utslagsgivande: 19 av 20 respondenter var kvinnor.

Ytterligare en materialkategori som jag, i viss mån, använder mig av i min analys är skönlitterära texter där städning utgör en tematik. Utan att jämställa de olika materialen - deras tillkomst, användningsområden och syften skiljer sig åt sinsemellan - har jag valt att betrakta dem alla som (olika) kulturella uttryck för människors erfarenheter av städning. Jag analyserar alltså inte de skönlitterära texterna i sin egen rätt eller som 
litterär genre. Snarare använder jag mig av dem för att frilägga föreställningsvärldar som blir möjliga att komma åt kanske särskilt väl genom den skönlitterära formen (jfr Pettersson och Svanström 2015).

Avslutningsvis vill jag säga några ord om studiens form. Bortsett från inledningen är boken indelad i fem kapitel, varav fyra är empiriskt förankrade. I kapitel två, „Varför skurar kvinnor toaletten?«, fördjupar jag mig i städningens envetna koppling till kvinnor och kvinnligt genus. Med utgångspunkt i några av intervjupersonernas berättelser prövar jag hur teorier om temporalitet, genom ett fokus på de kroppsliga erfarenheterna av att städa, kan ge perspektiv på sysslans till synes konserverande kraft. Här synliggörs också hur städningens genuskodning genomsyras av andra maktrelationer, såsom klass, sexualitet och rasifiering.

I kapitel tre, „Städningen och jämställdheten«, undersöker jag den centrala roll städning har i frågan om jämställdhet mellan könen. Med tiden som ingång, det fokus på städning som förhandlad fritid, obetald arbetstid och »bortkastad» tid som framkommer i intervjuerna, undersöks städningen som en jämställdhetens brännpunkt. Vem åker på slitgörat? Hur ser förhandlingarna ut? Och vad säger oss dessa förhandlingar om städning som syssla? Jag vänder också på frågan och undersöker hur förhållningssättet till städning, i det samtida Sverige där RUT-avdraget gjort städhjälp i hemmet både mindre laddat och mer möjligt för de som har råd, genererar en viss syn på jämställdhet.

Vad städning egentligen är för sorts syssla diskuteras i kapitel fyra, »Ett riktigt arbete?». Genom historiska nedslag, en sorts fallstudier, undersöks den glidning i betydelse mellan omsorg 
och arbete som karakteriserar städning i hemmet. Med särskilt fokus på städningens tid och plats skissas en historik av hur den privata städningen i hemmet har behandlats och betraktats över tid.

Städningen som omsorgsarbete står i fokus i kapitel fem, som fått sitt namn efter en av intervjupersonerna ofta upprepad uppmaning om vikten av att "ta hand om sin egen skit». Vad betyder denna uppmaning i informanternas vardag? Hur ska omhändertagandet förstås, vad är att betrakta som »den egna» och hur inverkar själva »skiten" på upplevelsen av arbetet?

I kapitel sex, "Städningens politik», tar jag ett samlat grepp om min ursprungliga fråga: Hur kommer det sig att städning har så låg status i samhället? Genom att diskutera städningens särskilda förhållande till temporalitet, resonerar jag kring vad det repetitiva, simproduktiva«, omsorgsarbetet kan tänkas bära på för sorts feministisk uppmaning. Således vill jag också slå ett slag för städning som utgångspunkt för en feministisk politik. 